\title{
DOl: https://doi.org/10.24297/jssr.v18i.9171
}

\section{A Review on Technology-Based Learning Management Innovations During and After The COVID-19 Pandemic Crisis}

\author{
Hadriana \\ Faculty of Teacher Training and Education Faculty University of Riau, Pekanbaru, Riau, Indonesia \\ hadriana@lecturer.unri.ac.id
}

\begin{abstract}
By the end of 2021, it has been almost two years that schools in various parts of the world have not been able to carry out face-to-face learning activities due to the Covid-19 pandemic. In this situation, online learning is considered to be the best solution so that learning activities can continue. However, the continuous implementation of online learning for a long time has resulted in learning loss - the condition of decreasing students' abilities and skills in cognitive, affective, and psychomotor aspects. To prevent the exacerbation of learning loss conditions, educators must continue working together to innovate in utilizing technology in learning activities. The use of digital technology is useful to control the implementation of learning and education management, especially after the emergence of COVID-19. That way technology becomes the most important part in helping the online learning process.
\end{abstract}

Keywords: Learning management, online learning, learning loss, COVID-19

\section{Introduction}

The word 'management' is often heard in our daily lives. This word can actually mean a profession or a system. It has the connotation of a profession since it must be based on special skills to obtain the position of 'manager,' and it has the meaning of a system as it comprises components that work together to achieve goals that have been set. Management is a process to plan, organize, and evaluate activities in order to achieve objectives (Purwanto, 2016). 'Effective' means that the activities are completed accurately, orderly, and on time, whereas 'efficient' means that the goals can be fulfilled according to a plan. Management is a fundamental component that will always be present and will be used as a guide by a manager when carrying out tasks (Amtu, 2013).

Furthermore, Amtu (2013) defines three different functions of management, namely: (1) planning, an activity of decision-making to set goals and to determine how to achieve the stated goals; (2) actuating, the overall endeavour, methods, techniques, or methods to encourage members in order to work together to achieve the objectives effectively, efficiently, and economically; and (3) evaluation, monitoring and managing performance to make certain that tasks are carried out in accordance with the predetermined plan.

Learning management is one part of management in which the activities are carried out in schools. it can be interpreted as teaching and learning activities carried out by teachers and organized in such a way as to allude to the efforts to govern learning activities. To realize the vision, mission and goals of an educational institution, these efforts must be based on concepts and principles. So that in the end the vision, mission and goals that have been outlined can be achieved more effectively, efficiently and productively. In other words, learning management refers to stages which include lesson planning, implementation and evaluation activities which are useful to measure the achievement of learning objectives.

As a manager as well as a leader in his school, a principal's duty is to organize, direct, and empower all of the school's potentials in order to fulfil the objectives that have been determined (Hadriana, 2021). Learning management is measured by activities such as planning, implementing, and assessing the learning process. Because changes in education are unavoidable, schools must be more adaptable and receptive to the many methods for achieving school goals, both short- and long-term (Hamzah et al., 2018).

In addition to the principal, the teacher is the main component responsible for achieving learning objectives. This is because the teacher is the person who has direct contact with the students when carrying out the teaching and learning process. Teachers have a very strategic role in the formation of knowledge, skills, and 
character of students. Therefore, to be able to produce good quality of educational products, professional teachers with high ability, quality and performance are needed very much. Only teachers who have these characteristics are able to carry out their duties in producing good quality students.

\section{Technology-Based Learning Management}

Until the end of 2021, it has been almost two years for schools in various parts of the world to not be able to carry out face-to-face learning activities due to the Covid-19 pandemic. At the beginning of the Covid19 pandemic, school principals, teachers, parents and other school societies were confused about how to carry out learning activities properly. In a relatively short time, to flatten the curve of COVID-19 cases, the administration decided that learning activities should be carried out online from home. The deployment of online learning activities at the time had led to many issues due to the limited infrastructure, finance as well as insufficient knowledge of the teachers in using technology (Z. R \& Saugi, 2018). However, online learning is considered to be the best solution can be done in order that learning activities can continue.

There are several terms that later developed related to the term of online learning. Some call it e-learning, distance learning, virtual learning, and others. In principle, all are the same. In the teaching and learning process, teacher and students do not have to meet face to face but are connected to each other by technological devices such as computers, laptops, smartphones and internet networks. Like face-to-face learning, teachers are required to always provide excellent service in accordance with applicable educational standards when teaching online. This means that teachers must be able to manage the teaching and learning process starting from the lesson planning stage, implementation up to evaluation stage (Saifulloh \& Darwis, 2020).

Over time, online learning began to cause various obstacles and serious problems that were not thought of before. The continuous implementation of online learning for a long time has resulted in learning loss - the condition of decreasing students' abilities and skills in cognitive, affective, and psychomotor aspects. This condition is also supported by the statement of the Indonesian Minister of Education and Culture, Nadiem Makarim, in a press conference broadcast on the Ministry of Education and Culture's YouTube account on Friday, August 7, 2020 - which said that learning loss is a decrease in students' learning competence.

Currently, learning loss is a global problem that is indicated to not stop even though Covid-19 is over. A professor from Oxford University Michelle Kaffenberger added that the crisis of declining learning abilities will not stop, even if schools reopen. In Indonesia, however, learning loss can continue if the government and schools do not implement a policy to restore learning abilities first (Andre, 2021). The current condition of Indonesian education has led to a learning loss condition. It is proven by the results of a survey conducted by the Indonesian Ministry of Education and Culture on schools regarding the potential for learning loss as the impact of implementing online learning. The survey results show that nationally there are 20 percent of schools that state that some students do not meet the targeted competencies as a result of online learning. In other words, they experience learning loss. Students' learning motivation in participating in online learning also makes the situation worse. The decrease in learning motivation during online learning happens because the students are 'forced' to learn and understand the subject matter independently (Cahyani, 2020).

The negative impact caused by learning loss is not only on students, but also on the fate and progress of the Indonesian nation in the future. If learning loss continues to occur and this problem is not immediately resolved, in approximately 15 years this nation will experience the loss quality of next generation. School closures in reaction to the COVID-19 pandemic has caused a risk of damaging children's education, safety, and welfare (Masterman, 2020).

On the other hand, today we live in the Industrial Revolution 4.0 stage, an era that has such a big influence on the education world in Indonesia. The learning system in schools that was initially face-to-face must slowly be changed to a technology-based approach. It includes all technologies related to the handling of information which includes retrieval, collection, processing, storage, dissemination, and presentation of information. 
Through the utilization of ICT, learning activities shift from teacher-centered to student-centered. Teachers must be able to become facilitators and motivators for students to find and utilize learning resources through digital technology development. This is also an inspiration for students to be more active in learning and looking for learning resources of information by using technology. Through the utilization of ICT, students are no longer behave as passive participants but are required to be active. The utilization of ICT also encourages creativity and independence in learning. Creative in generating and creating new information or knowledge and independent in finding various subject matter for knowledge enrichment. Creativity and learning independence formed by the integration of ICT in learning activities make students as individuals who are able to compete. Looking at these great benefits of ICT, many teachers mention that they were motivated to utilize ICT whether as teaching media or as learning resources. Further, they have their own ways to overcome obstacles they face in the application of using ICT. Generally, the obstacles are related to limited infrastructure, as well as the insufficient capabilities they have (Hadriana, 2019).

In relation to preventing the worsening of learning loss conditions, we academics must continue working together to innovate in utilizing technology in learning activities. Javaid et al. (2020) conveyed how the currently available industrial 4.0 technology helps the sustainability of education and diagnoses problems related to Covid-19. They recommended that the use of adopted digital technology is a systematic way of designing, implementing, and evaluating the overall learning process to achieve specific learning objectives. The use of digital technology is useful to control the implementation of learning and education management, especially after the emergence of Covid-19. That way technology becomes the most important part in helping the online learning process.

This opinion is in line with the opinion of the former Minister of Education of the Republic of Indonesia Nuh (2021) who encourages education practitioners to 'make digital technology a lifestyle'. The point is that teaching styles of teachers need to depart from their habits in the digital world. To put it simply, digital learning systems do not require face-to-face learning at the time of learning. When the learning material already exists in the form of videos, learning can be carried out anytime, anywhere. A change of mindset is needed where learning hybrid from home is not teaching by moving the whiteboard into the application. The implementation of digital literacy training and the use of technology can be one solution in dealing with several online learning challenges (Salsabila, 2020)

Education experts have also conducted comprehensive research on the implementation of learning in order to prevent learning loss during the Covid-19 pandemic. One of the recommendations given is through the implementation of an education system that applies $21^{\text {st }}$-century skills. So far, there is no single, universally accepted definition of 21 st Century skills. There are various descriptors of $21^{\text {st }}$-century skills given. So that it becomes a debate among stakeholders (Suto, 2013). However, it is certain that $21^{\text {st }}$-century skills will be acquired by students only through innovative $21^{\text {st }}$-century learning.

Innovative learning in the $21^{\text {st }}$-century refers to the framework for learning with components such as: (1) learning environment, (2) professional ability development, (3) curriculum and instructional, and (4) standards and assessments. These four components become the entry gate to enter the era of globalization in order to be able to compete in the working world. Framework for $21^{\text {st }}$-century learning demonstrates the competencies, knowledge and expertise that must be mastered so that the students are able to gain success in their life and career. The framework is clearly described as follows. 


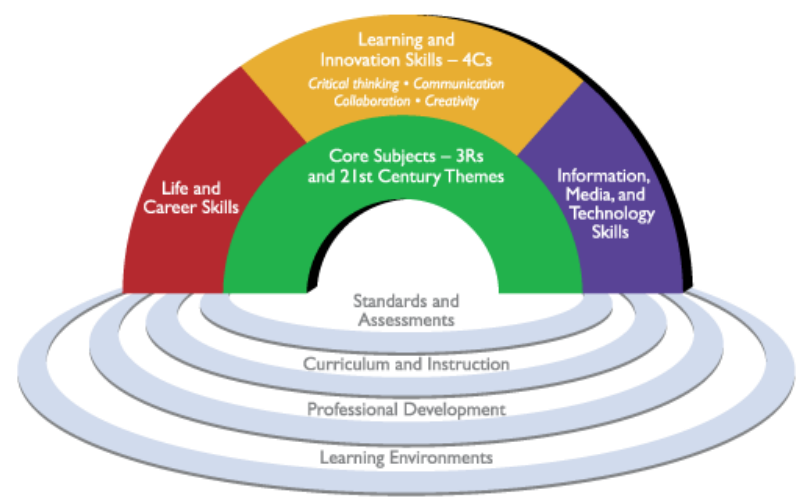

Figure 1. $21^{\text {st }}$-Century Learning Framework

(Partnership for 21st Century Learning, 2015)

Fig. 1 shows that having knowledge of core subjects only is not enough, which means that someone must possess the following abilities:

1. Creative and innovative learning and abilities such as critical thinking and problem solving, creativity and innovation, communication, and cooperation.

2. Personal and professional qualities such as adaptability, initiative, and independence, as well as social and cultural skills, productivity, accountability, and leadership and responsibility.

3. Information, media, and technology skills imply that students must be literate in information, media, and ICT.

Referring to the framework, the government must continue to improve and develop the quality of education so that the human resources produced are able to compete in the era of globalization. Various efforts have been done by the government related to the framework, namely: (1) adjustment of national education standards by referring to the achievement of educational standards at the international level, (2) periodic and continuous review and revision of the curriculum, (3) develop professional skills for human resources, (4) develop learning environment.

An education system that prioritizes $21^{\text {st }}$-century skills is based on Technological Pedagogical Content Knowledge (TPCK), namely teacher's knowledge about the material to be taught (content knowledge), how the teacher teaches subject matter (pedagogical knowledge), and teacher's knowledge about the use of various technologies in learning activities (technological knowledge). These four skills are related to each other to support the learning process (Mahdum, 2015). According to Suto (2013). The 21st century skills are: (1) Creativity and originality; (2) critical thinking, problem solving, and decision making; (3) Metacognition (learning to learn): (4) Communication; (5) Collaboration; (6) Information literacy; (7) ICT literacy; (8) Local and global skills; (9) Life and career skills; and (10) personal and social responsibility including cultural understanding and competency.

The National Educational Technology Standards for Students (NETS-S) reveals that there are 6 important skills that students must have and are taught by teachers in schools. These skills are: (1) Creativity and innovation; (2) Communication and collaboration; (3) Research and fluency of information; (4) critical thinking, problem solving and decision making; (5) Digital citizenship; and (6) technology operations and concepts. Nichols \& Jennifer (2017) then simplify these six skills into four major principles of $21^{\text {st }}$-century learning:

1. Instruction should be focussed on the students. A learner-centered learning method should be used in learning development. Students are encouraged to pursue their passions and maximize their potential. They are no longer required to memorize the material explained by the teacher, but instead are encouraged to build their own knowledge and skills based on their capacity and level of thinking development, while also being asked to take part in the solution of real-world problems. 
2. Learning should be a shared effort. Students need to learn how to work cooperatively with others. Collaborating with people who come from different cultural backgrounds and hold different values is encouraged through working with their classmates when collecting information and constructing meaning. Students must learn how to value each person's strengths and traits when working on a project, as well as how to take on roles and adjust to them correctly.

3. Learning should contextual. Learning will be meaningless if it has no impact on students' lives outside of school. Thus, subject content must be connected to students' daily lives, and teachers must develop teaching approaches that enable students to relate to the actual world.

4. Schools should be socially integrated. They should be able to encourage students' involvement in their social surroundings in order to prepare them to become useful adults. For example, by involving them in various program developments in community, such as health, education, and the environment.

To be able to teach these skills to students, there are a series of characteristics that the teachers must possess. (Syahputra, 2018):

1. Have a high interest in reading. Can you imagine if the teacher's interest in reading is low, what will happen? Surely the knowledge of the teacher will stagnate and be exceeded by the knowledge of the students. The implication is that the teacher's authority declines in the eyes of students.

2. Have the competency to write scientific papers. Teachers are also required to have the academic writing ability because in their daily life they will always provide various kinds of assignments. This requires teachers to be proficient in writing.

3. Creative and innovative in practicing various learning models. Creative and innovative teachers are able to practice learning models in order to construct students' knowledge. The combination of the use of learning models and digital technology will lead to creativity and innovation of students.

4. Able to transform culturally. The teacher-centered view of the previous learning culture must be able to transform towards student-centered perspective, turning students into learning subjects who can construct their knowledge maximally.

Another important thing to do is to understand that mitigating the potential for learning loss is not only pays attention to the elements of information technology, but also requires a curriculum rearrangement that is more in line with 21st century skills (Alam, 2020). Curriculum revisions must be redesigned in depth for all dimensions of education which include: (1) knowledge, (2) skills, (3) character, and (4) meta-learning to be adapted to the needs of the 21st century. The relationship and interaction of these dimensions can be seen in the following figure. 


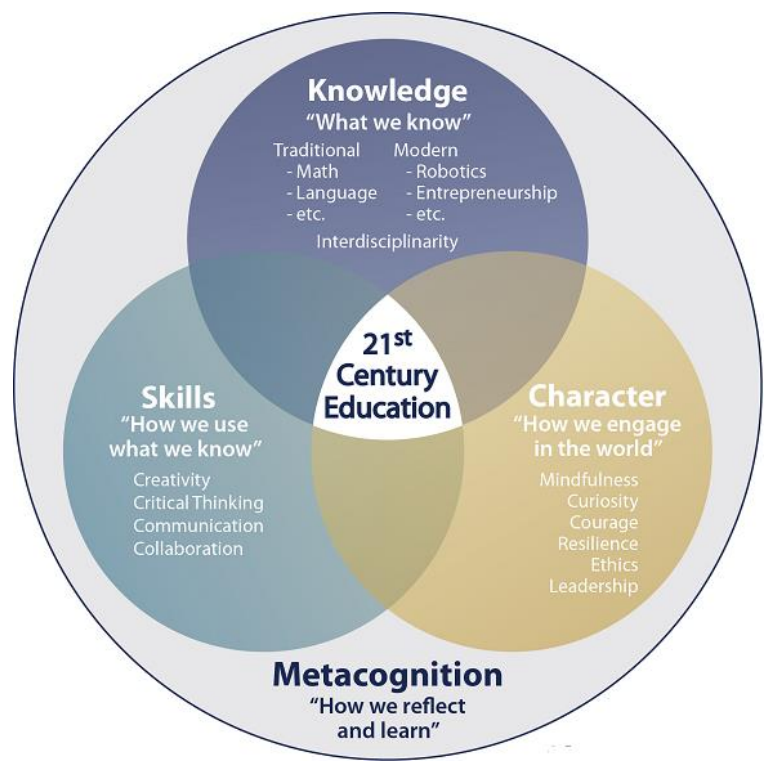

Figure 2. Interaction of 21st Century Education Dimensions

\section{(Center for Curriculum Redesign, n.d.)}

From Fig. 2 it can be explained that:

1. Knowledge - what we are aware of and comprehend. In the traditional view, knowledge is the most important dimension in education. However, with increasing knowledge collectively, the curriculum has not succeeded in following it. Current curricula are often irrelevant to learners for their social and economic needs. So, there is a need for rethinking the curriculum in order to balance the theory and practice.

2. Skills - How we use what we know. High-level skills: creativity, critical thinking, communication, collaboration are very important to learn knowledge in depth and show understanding through performance (Fadel \& Trilling, 2015). Content-burdened curricula make it more difficult for learners to acquire skills.

3. Character - How we act and interact in the real world. There has been a heightening need for quality development rather than just knowledge and skills, namely character education, which has three general goals: (1) laying the groundwork for lifelong learning; and (2) fostering successful relationships at home, in the community, and at work, (3) strengthening personality values and participating sustainably in a globalized world. The Center Curriculum Redesign (CCR) has incorporated over 32 frameworks, research and feedback to arrive at six essential character qualities, which are: (1) mindfulness, (2) curiosity, (3) courage, (4) resilience, (5) ethics, and (6) leadership (Fadel, 2015).

4. Meta Learning - how we contemplate and adjust. Meta-learning refers to the processes associated with reflection and adjustment of learning, which includes metacognition and developing growth mindsets about someone's capabilities. This process is vital for fostering lifelong learning habits and other three-dimensional learning, and ensuring the transfer of learning outside of its original context. Meta-learning can explicitly help learners in all areas throughout their life and careers.

It appears that education in the 21st century requires teachers and students to have a large amount of complex knowledge accompanied by various skills such as: higher-order thinking skills, skills in the world of work, skills in using information, technology media in accordance with the $21^{\text {st }}$-century innovative learning framework proclaimed by Partnership for 21st Century Learning (2011). If all of these can be implemented, it is not impossible that the risks caused by learning loss can be minimized or even eliminated. 


\section{Conclusions}

The occurrence of the Covid-19 pandemic has caused learning loss among students not only in Indonesia, but also all over the world. We academics must help each other and do various effort in solving the problems. One way that can be done is to improve the education system through good learning management. Teachers need to innovate in implementing learning models through the use of digital technology and making technology a lifestyle. Furthermore, learning activities need to refer to 21 st century learning activities so that students have 21 st century innovative skills that refer to the framework for 21 st century skills.

\section{References}

Alam, S. (2020, September 14). Mitigasi learning loss [Learning loss mitigation]. Medialndonesia. https://mediaindonesia.com/opini/344616/mitigasi-learning-loss

Amtu, O. (2013). Manajemen pendidikan di era otonomi daerah [Educational management in the era of decentralization]. Alfabeta.

Andre, Y. (2021, March 1). Learning loss mengancam anak Indonesia, ini solusinya [Learning loss threatened Indonesian children, here's the solutions]. FigurNews. https://www.figurnews.com/2021/03/learning-loss-mengancam-anak-indonesia.html.

Battelle for Kids. (n.d.). Framework for 21st century learning. http://www.p21.org/our-work/p21framework

Cahyani, A., Listiana, I, D., \& Larasati, S. P. D. (2020). Motivasi belajar siswa SMA pada pembelajaran daring di masa pandemi COVID-19 [High school students' motivation on online learning during COVID-19]. IQ (Ilmu Al-Qur'an): Jurnal Pendidikan Islam, 3(1), 137. https://doi.org/10.37542/iq.v3i01.57

Center for Curriculum Redesign. (n.d.). What should students learn for the 21st century? https://curriculumredesign.org

Fadel. C., Bialik . M., \& Trilling. B., (2015). Four-dimensional education: The competencies learners need to succeed. Center for Curriculum Redesign.

Hadriana, 2019. Self-efficacy and Attitude of the Teachers of SMAN Kuansing District towards the Utilization of ICT. Journal of Educational Sciences, 3(1), 25-37. https://doi.org/10.31258/jes.3.1.p.25$\underline{37}$

Hadriana, Mahdum, Isjoni, Futra, D., \& Primahardani, I. (2021). Online learning management in the era of COVID-19 pandemic at junior high schools in Indonesia. Journal of Information Technology Education: Research, 20, 351-383. https://doi.org/10.28945/4819

Hamzah, D. S., Ibrahim, M. S., \& Ghavifekr, S. (2018). Change orientation and organizational climate: Experience from Malaysian primary schools. Malaysian Journal of Educational Management, 6(2), 83-109. https://doi.org/10.22452/mojem.vol6no2.5

Javaid, M., Haleem, A., Vaishya, R., Bahl, S., Suman, R., \&amp; Vaish, A. (2020). Industry 4.0 technologies and their applications in fighting COVID-19 pandemic. Diabetes \& Metabolic Syndrome: Clinical Research \& Reviews, 14(4), 419-422. https://doi.org/10.1016/j.dsx.2020.04.032

Mahdum. (2015). Technological Pedagogical and Content Knowledge (TPACK) of English Teachers in Pekanbaru, Riau, Indonesia. Mediterranean Journal of Social Sciences, 6(5), 168-176. https://doi.org/10.5901/mjss.2015.v6n5s1p168

Masterman, C. (2020). Stay-at-home orders and COVID-19 fatalities. SSRN Electronic Journal. https://doi.org/10.2139/ssrn.3600905 
Nichols, J. R. (2021, December 29). 4 Essential rules of 21st-century learning. TeachThought. https://www.teachthought.com/learning/rules-of-21st-century-learning/

Nuh. M., (2021, August 26). Cara cegah learning loss karena COVID-19: Pendidikan perlu manfaatkan teknologi [Ways to prevent learning loss due to COVID-19: Education needs to use technology]. Sevima. https://sevima.com/cara-cegah-learning-loss-karena-covid/

Purwanto, N. (2016). Administrasi dan supervisi pendidikan [Education administration and supervision]. Remaja Rosdakarya.

Saifulloh, A. M., \& Darwis, M. (2020). Manajemen pembelajaran dalam meningkatkan efektivitas proses belajar mengajar di masa pandemi COVID-19 [Learning management to improve teaching and learning effectivity]. Bidayatuna: Jurnal Pendidikan Guru Mandrasah Ibtidaiyah, 3(2). https://doi.org/10.36835/bidayatuna.v3i2.638

Salsabila, U. H., Sari, L. I., Lathif, K. H., Lestari, A. P., \& Ayuning, A. (2020). Peran teknologi dalam pembelajaran di masa pandemi COVID-19 [The role of technology in learning during COVID-19 Pandemi]. Al-Mutharahah: Jurnal Penelitian Dan Kajian Sosial Keagamaan, 17(2), 188-198. https://doi.org/10.46781/al-mutharahah.v17i2.138

Suto, I. (2013). 21st century skills: Ancient, ubiquitous, enigmatic? Paper Published in research matters: A Cambridge Assessment Publication. University of Cambridge.

Syahputra, E. (2018). Pembelajaran abad 21 dan penerapannya di Indonesia [21-century learning and its implementation in Indonesia]. Prosiding Seminar Nasional SINASTEKMAPAN, 1, 1276-1283.

Trilling, B., \& Fadel, C. (2009). 21st century skills: Learning for life in our times (1st ed.). Jossey-Bass.

Z.R, H. N., \& Saugi, W. (2020). Pengaruh kuliah online terhadap minat belajar mahasiswa Pendidikan Agama Islam (PAI) di IAIN Samarinda [The effect of onlinelearning towards students' learning interest in Religion subject (PAI) at IAIN Samarinda]. El-Buhuth: Borneo Journal of Islamic Studies, 2(2), 121-131. https://doi.org/10.21093/el-buhuth.v2i2.2330

\section{Conflicts of Interest}

I have no conflicts of interest to disclose.

\section{Funding Statement}

N/A

Biography

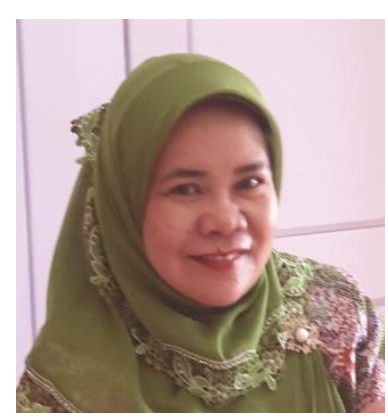

Hadriana holds a PhD in Resource and Information Technology from The National University of Malaysia. She is a lecturer in the Faculty of Teacher Training and Education, Riau University. Her areas of research interest include educational technology in English language teaching and Teaching English as a Foreign Language (TEFL). She has presented papers in national and international conferences on ICT in education. 